
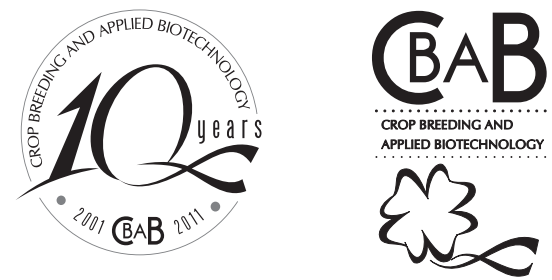

\title{
Sources of resistance to Curtobacterium flaccumfaciens pv. flaccumfaciens in common bean accessions
}

\author{
Giseli Valentini ${ }^{1}$, Joana Neres da Cruz Baldissera ${ }^{1}$, Fabiani da Rocha ${ }^{1}$, Carmelice Boff de Almeida ${ }^{1}$, Joice Crescêncio Heidemann ${ }^{1}$, \\ Altamir Frederico Guidolin ${ }^{1 *}$ and Jefferson Luís Meirelles Coimbra ${ }^{1}$
}

Received 3 September 2010

Accepted 15 November 2010

\begin{abstract}
The purpose of this study was to identify common bean genotypes resistant to bacterial wilt to be used as resistance sources in breeding programs targeting resistant cultivars. A total of 67 accessions, five cultivars and one control were evaluated, which were artificially inoculated with the Curtobacterium flaccumfaciens $p v$. flaccumfaciens isolate Cff 2634 . The results prove the existence of alleles that confer tolerance to bacterial wilt in the cultivars IAC Carioca Aruã, IAC Carioca Pyatã and IAC Carioca Tybatã. The mean grades of disease symptoms were lowest in BAF 122 (Xan 159); this accession was identified as disease-tolerant and indicated for use in breeding programs to develop resistant cultivars.
\end{abstract}

Key words: Phaseolus vulgaris L., bacterial wilt, living genebank.

\section{INTRODUCTION}

Common bean (Phaseolus vulgaris L.) is the world's second most produced and consumed legume species, and highly important in the national and global agricultural production. However, the crop is susceptible to a number of external factors, for example climatic influences and disease incidence, which contribute to the reduction of grain yield. Recently, Curtobacterium wilt or bacterial wilt caused by Curtobacterium flaccumfaciens pv.flaccumfaciens was detected in several bean-producing regions of Brazil (Maringoni and Rosa 1997, Uesugi et al. 2003, Theodoro et al. 2004), a fact that has motivated research indicating bacterial wilt as one of the most important emerging diseases of common bean.

The survival of the pathogen in contaminated crop residues, soil and seed, along with the fact that common bean is grown throughout the country and practically all year long, helps the bacterium Curtobacterium flaccumfaciens pv. flaccumfaciens to survive for long periods and spread out into new regions. In common bean cultivation, the utilization rate of controlled seed is very low (around $20 \%$ in Santa Catarina), since farmers mostly use seeds from their own production (Herbes et al. 2008). This is a phytosanitary problem, since contaminated seeds are the most efficient means of bacteria dissemination, especially over long distances.

The control of bacterial wilt is based on the use of resistant cultivars, crop rotation and healthy seeds (Maringoni and Camara 2006, Herbes et al. 2008) since there are no products available for a chemical control of the wilt. After the appearance in the field, the bacteria on infected plants can only be controlled by eliminating the diseased plants (Romero 2005). The use of resistant

\footnotetext{
${ }^{1}$ Universidade do Estado de Santa Catarina, Centro de Ciências Agroveterinárias, Instituto de Melhoramento e Genética Molecular, Av. Camões, 2090, 88.520-000, Lages, SC, Brazil. *E-mail: a2afg@ cav.udesc.br
} 
cultivars is the most efficient way to control bacterial wilt and is also cheap and easy to use for farmers.

To meet the need for resistant genotypes, the identification of bean genotypes with good resistance levels is essential for the development of a breeding program, facilitating the incorporation of resistance genes into highyielding, susceptible genotypes (Maringoni 2002, Souza et al. 2006, Theodoro et al. 2007, Krause et al. 2009). For this purpose, the collections in the living genebanks contain a huge variability of genes, which must be characterized for the use in breeding programs.

The objective of this study was to identify common bean genotypes resistant to bacterial wilt as resistance source in breeding programs.

\section{MATERIAL AND METHODS}

From the living genebank of common bean of the State University of Santa Catarina (UDESC) 67 accessions, five cultivars (IAC Carioca Aruã, IAC Carioca Pyatã, IAC Carioca Tybatã, SCS Guará and Pérola) and a control (IAPAR 81) were evaluated.

The experiment was conducted in a greenhouse in a completely randomized design with three replications. Each experimental unit consisted of one pot containing three plants. The soil used was a mixture of mineral earth, composted cattle manure and substrate. Five seeds were sown and after emergence thinned to three plants per pot.

Nine days after emergence the plants were inoculated according to the methodology of Maringoni (2002). Curtobacterium flaccumfaciens pv. flaccumfaciens isolate Cff 2634 was used, which was grown in nutrient-sucrose agar (NSA) culture medium for 48 hours at $28^{\circ} \mathrm{C}$ in a bacteria growth chamber. Then the bacteria were diluted in saline solution $(0.85 \% \mathrm{NaCl})$ to a concentration of $10^{8}$ u.f.c. $\mathrm{mL}^{-1}$, measured by a spectrophotometer at an optical density of $600 \mathrm{~nm}$. The stems were inoculated at two perforations between the cotyledons and primary leaves, with a stick previously soaked in bacterial solution. In the control treatment (IAPAR 81) the bean plants were perforated at two points and treated with distilled water as a surrogate for the bacterial solution.

The disease symptoms were assessed 20, 30 and 40 days after inoculation, on a grade scale adapted by Maringoni (2002). Reactions of genotypes with grades up to two were considered tolerant (Theodoro and Maringoni 2006, Theodoro et al. 2007).
Considering that the assessments were performed in the same experimental unit, the analysis of repeated measures over time was used (Littell et al. 2006), based on the statistical model:

$Y_{i j}=\mu+g_{i}+t_{j}+g t_{i j}+e_{i j}$, where $: Y_{i j}$ is the observed value of genotype $i$ at time $j ; \mu$ is the overall mean, $g_{i}$ is the effect of genotype $i ; t_{j}$ is the effect of time $j ; g t_{i j}$ is the interaction effect genotype $i$ at time $j$; and $e_{i j}$ is the random error. To meet the assumption of normality of the statistical model, the data were transformed by $\sqrt{x+\frac{3}{8}}$, and tested for normality by Shapiro-Wilk.

To model the covariance matrix of residuals 15 structures were tested. The Akaike Information Criterion was used to choose the covariance matrix, selecting the lowest value for this parameter. The partitioning of the degrees of freedom for each genotype over time was performed by linear regression analysis, adjusting polynomials. All procedures were performed using PROC MIXED and PROC GLM of SAS according to Littell et al. (2006).

\section{RESULTS AND DISCUSSION}

The covariance matrix that best fit the data was a first-order ante-dependence matrix (ANTE 1). This matrix considers the heterogeneity of variance and correlation between the errors of adjacent evaluation periods and allows an appropriate modeling of the errors associated with the means, corroborating the conclusions of analysis of variance and increasing the accuracy of estimates of the associated mean error (Littell et al. 2006).

The effect of genotype - time interaction was significant ( $\mathrm{Pr}>\mathrm{F}=0.0006)$, indicating that the genotype performance was different in the evaluation periods of bacterial wilt and that the effect time had the greatest influence on the significance of the interaction (data not shown).

Since the genotype - time interaction was significant, the degrees of freedom were partitioned, demonstrating the behavior of each genotype in the evaluations. Due to the large number of genotypes some representative graphs are shown in Figure 1, with low, intermediate and high mean grades of bacterial wilt symptom. The mean of all evaluated genotypes, as well as the slope coefficients and coefficients of determination $\left(\mathrm{R}^{2}\right)$ are presented in Table 1. Bacterial wilt symptoms were observed on all accessions, although at different levels, which all fit the model of linear disease growth over time ( $\mathrm{R}^{2}$ of $\left.0.88-0.97\right)$ (Table 1). The appearance of bacterial wilt on all accessions 
Table 1. Mean grades for bacterial blight symptoms 20, 30 and 40 days after inoculation, coefficient angular and coefficient of determination $\left(\mathrm{R}^{2}\right)$ for the 72 genotypes

\begin{tabular}{|c|c|c|c|c|c|c|c|c|c|c|c|}
\hline \multirow{2}{*}{ Genotype } & \multicolumn{3}{|c|}{ Means (days) } & \multirow{2}{*}{$\begin{array}{c}\text { Slope } \\
\text { coefficient }\end{array}$} & \multirow{2}{*}{$\mathbf{R}^{2}$} & \multirow{2}{*}{ Genotype } & \multicolumn{3}{|c|}{ Means (days) } & \multirow{2}{*}{$\begin{array}{c}\text { Slope } \\
\text { coefficient }\end{array}$} & \multirow{2}{*}{$\mathbf{R}^{2}$} \\
\hline & 20 & 30 & 40 & & & & 20 & 30 & 40 & & \\
\hline BAF01 & 0.33 & 2.33 & 3.67 & $y=0.08 x^{*}$ & 0.92 & BAF81 & 1.50 & 4.50 & 7.50 & $y=0.12 x^{*}$ & 0.97 \\
\hline BAF02 & 1.00 & 4.00 & 6.33 & $y=0.10 x^{*}$ & 0.94 & BAF84 & 1.00 & 3.00 & 4.00 & $y=0.09 x^{*}$ & 0.93 \\
\hline BAF05 & 1.33 & 4.00 & 5.67 & $\mathrm{y}=0.10 \mathrm{x}^{*}$ & 0.95 & BAF86 & 2.33 & 3.33 & 5.00 & $\mathrm{y}=0.10 \mathrm{x}^{*}$ & 0.93 \\
\hline BAF07 & 3.00 & 6.33 & 7.33 & $y=0.12 x^{*}$ & 0.96 & BAF87 & 2.00 & 6.50 & 7.50 & $y=0.12 x^{*}$ & 0.93 \\
\hline BAF08 & 2.00 & 5.00 & 7.67 & $y=0.12 x^{*}$ & 0.94 & BAF88 & 1.00 & 4.33 & 6.67 & $y=0.11 x^{*}$ & 0.93 \\
\hline BAF09 & 1.33 & 3.00 & 4.67 & $y=0.09 x^{*}$ & 0.93 & BAF89 & 1.67 & 5.33 & 7.00 & $\mathrm{y}=0.11 \mathrm{x}^{*}$ & 0.92 \\
\hline BAF10 & 1.00 & 1.00 & 3.67 & $y=0.08 x^{*}$ & 0.92 & BAF90 & 1.67 & 4.67 & 6.00 & $y=0.11 x^{*}$ & 0.94 \\
\hline BAF11 & 1.00 & 4.33 & 6.67 & $\mathrm{y}=0.11 \mathrm{x}^{*}$ & 0.96 & BAF91 & 1.00 & 5.67 & 7.67 & $\mathrm{y}=0.12 \mathrm{x}^{*}$ & 0.95 \\
\hline BAF13 & 1.67 & 5.33 & 6.67 & $\mathrm{y}=0.11 \mathrm{x}^{*}$ & 0.95 & BAF92 & 0.33 & 6.00 & 6.67 & $\mathrm{y}=0.11 \mathrm{x}^{*}$ & 0.92 \\
\hline BAF14 & 1.00 & 5.33 & 7.67 & $y=0.11 x^{*}$ & 0.93 & BAF95 & 0.33 & 3.00 & 4.00 & $\mathrm{y}=0.09 \mathrm{x}^{*}$ & 0.92 \\
\hline BAF23 & 1.00 & 1.67 & 2.67 & $y=0.07 x^{*}$ & 0.83 & BAF97 & 0.67 & 2.33 & 3.33 & $y=0.08 x^{*}$ & 0.89 \\
\hline BAF24 & 1.67 & 4.67 & 7.33 & $y=0.11 x^{*}$ & 0.96 & BAF98 & 1.00 & 4.33 & 5.67 & $\mathrm{y}=0.10 \mathrm{x}^{*}$ & 0.95 \\
\hline BAF25 & 1.67 & 6.00 & 8.67 & $y=0.12 x^{*}$ & 0.97 & BAF99 & 0.67 & 3.33 & 6.67 & $\mathrm{y}=0.10 \mathrm{x}^{*}$ & 0.94 \\
\hline BAF27 & 0.67 & 3.67 & 5.33 & $y=0.10 x *$ & 0.92 & BAF101 & 2.00 & 5.00 & 6.33 & $\mathrm{y}=0.11 \mathrm{x}^{*}$ & 0.96 \\
\hline BAF28 & 3.00 & 7.00 & 8.33 & $y=0.13 x^{*}$ & 0.97 & BAF108 & 1.00 & 1.67 & 2.33 & $y=0.07 x^{*}$ & 0.90 \\
\hline BAF29 & 1.00 & 4.33 & 6.33 & $y=0.11 x^{*}$ & 0.94 & BAF109 & 0.00 & 3.33 & 6.00 & $y=0.09 x^{*}$ & 0.90 \\
\hline BAF34 & 1.00 & 1.33 & 3.67 & $y=0.08 x^{*}$ & 0.93 & BAF122 & 0.00 & 1.33 & 1.67 & $y=0.06 x^{*}$ & 0.80 \\
\hline BAF35 & 2.00 & 5.00 & 7.00 & $\mathrm{y}=0.11 \mathrm{x}^{*}$ & 0.94 & BAF127 & 1.00 & 3.00 & 4.67 & $\mathrm{y}=0.09 \mathrm{x}^{*}$ & 0.93 \\
\hline BAF37 & 2.33 & 5.67 & 7.33 & $y=0.12 x^{*}$ & 0.96 & BAF128 & 1.00 & 4.00 & 5.00 & $\mathrm{y}=0.10 \mathrm{x}^{*}$ & 0.94 \\
\hline BAF38 & 1.00 & 2.67 & 4.00 & $\mathrm{y}=0.09 \mathrm{x} *$ & 0.90 & BAF130 & 1.00 & 4.67 & 6.33 & $\mathrm{y}=0.11 \mathrm{x}^{*}$ & 0.94 \\
\hline BAF40 & 1.00 & 7.00 & 8.67 & $y=0.12 x^{*}$ & 0.95 & BAF131 & 1.00 & 2.00 & 4.33 & $\mathrm{y}=0.09 \mathrm{x}^{*}$ & 0.94 \\
\hline BAF42 & 1.67 & 5.67 & 8.33 & $\mathrm{y}=0.12 \mathrm{x}^{*}$ & 0.96 & BAF141 & 2.00 & 3.67 & 4.00 & $\mathrm{y}=0.10 \mathrm{x}^{*}$ & 0.93 \\
\hline BAF47 & 0.67 & 1.67 & 6.33 & $\mathrm{y}=0.09 \mathrm{x}^{*}$ & 0.93 & BAF143 & 0.50 & 5.00 & 7.50 & $\mathrm{y}=0.11 \mathrm{x}^{*}$ & 0.94 \\
\hline BAF49 & 0.00 & 1.33 & 4.67 & $y=0.08 x^{*}$ & 0.88 & BAF144 & 1.00 & 5.00 & 7.33 & $y=0.11 x^{*}$ & 0.96 \\
\hline BAF50 & 0.67 & 1.33 & 3.00 & $y=0.07 x^{*}$ & 0.92 & BAF145 & 1.67 & 3.67 & 7.33 & $\mathrm{y}=0.11 \mathrm{x}^{*}$ & 0.95 \\
\hline BAF53 & 1.00 & 3.33 & 4.67 & $y=0.09 x^{*}$ & 0.94 & BAF147 & 1.50 & 5.00 & 8.00 & $y=0.12 x^{*}$ & 0.97 \\
\hline BAF56 & 0.67 & 2.33 & 3.33 & $y=0.08 x^{*}$ & 0.91 & BAF150 & 1.33 & 3.67 & 5.00 & $y=0.10 x^{*}$ & 0.94 \\
\hline BAF63 & 0.67 & 2.00 & 3.33 & $y=0.08 x *$ & 0.92 & BAF156 & 1.00 & 3.67 & 7.33 & $\mathrm{y}=0.11 \mathrm{x}^{*}$ & 0.95 \\
\hline BAF64 & 2.00 & 6.67 & 7.33 & $y=0.12 x^{*}$ & 0.96 & BAF162 & 1.33 & 4.00 & 7.33 & $y=0.11 x^{*}$ & 0.94 \\
\hline BAF65 & 1.00 & 5.33 & 8.00 & $\mathrm{y}=0.12 \mathrm{x}^{*}$ & 0.95 & BAF164 & 0.33 & 1.33 & 4.67 & $\mathrm{y}=0.08 \mathrm{x}^{*}$ & 0.88 \\
\hline BAF66 & 1.67 & 3.33 & 4.33 & $y=0.09 x *$ & 0.94 & BAF183 & 1.00 & 4.00 & 5.33 & $y=0.10 x^{*}$ & 0.83 \\
\hline BAF69 & 1.00 & 6.00 & 8.00 & $y=0.12 x^{*}$ & 0.96 & SCS Guará & 1.33 & 3.00 & 5.00 & $\mathrm{y}=0.10 \mathrm{x}^{*}$ & 0.93 \\
\hline BAF74 & 2.33 & 5.33 & 7.33 & $y=0.12 x^{*}$ & 0.96 & Pérola & 0.00 & 3.00 & 5.00 & $\mathrm{y}=0.07 \mathrm{x}^{*}$ & 0.88 \\
\hline BAF75 & 1.00 & 3.00 & 4.00 & $\mathrm{y}=0.09 \mathrm{x}^{*}$ & 0.89 & IAC Pyatã & 1.00 & 2.00 & 3.00 & $\mathrm{y}=0.09 \mathrm{x} *$ & 0.92 \\
\hline BAF78 & 1.67 & 4.67 & 5.33 & $\mathrm{y}=0.11 \mathrm{x}^{*}$ & 0.92 & IAC Tybatã & 0.67 & 2.33 & 3.67 & $y=0.08 x^{*}$ & 0.90 \\
\hline BAF79 & 0.33 & 2.33 & 3.33 & $y=0.08 x^{*}$ & 0.93 & IAC Aruã & 0.00 & 1.00 & 3.00 & $\mathrm{y}=0.07 \mathrm{x}^{*}$ & 0.92 \\
\hline
\end{tabular}

is due to the fact that the nature of the genetic control of the disease is complex, probably polygenic (Coyne et al. 1965).

A consequence of the complex nature of resistance and of the great influence of the environment on symptom development is a low heritability, an obstacle in the development of resistant cultivars (Mutlu et al. 2005). The prior knowledge of resistance sources enables the development of genotypes that are resistant or have acceptable tolerance levels, i.e., the yield is not affected.
In this sense, the living genebanks are particularly valuable because of the high variability of genes that can be used in breeding programs. In the living common bean genebank of UDESC, the mean grades of bacterial wilt symptom of BAF 122 (Xan 159) were below two in all three evaluations, suggesting that this accession has genes that induce tolerance to the disease (Table 1, Figure 1). For the correct choice of accessions the symptom grades must not only be low, but the disease progression over time should also be slow, as can be observed in the low slope 
G Valentini et al.
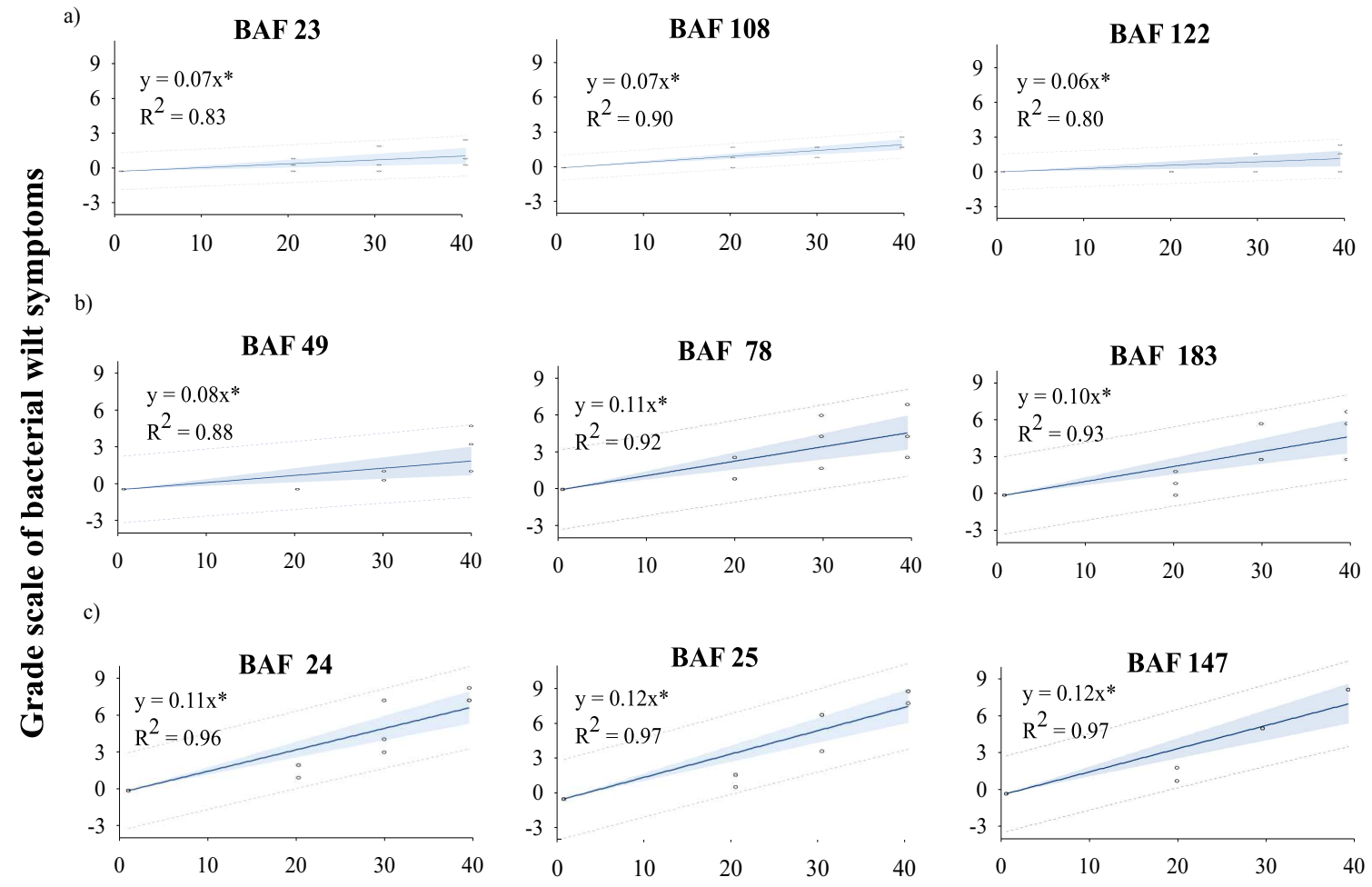

Time (days after inoculation)

Interval confident to $95 \%$ probability

Interval confident to $95 \%$ probability

Figure 1. Diagrams of grades of bacterial wilt symptoms of the respective evaluated genotypes 30 , 40 and 50 days after inoculation; confidence interval at $95 \%$ probability; predicted interval at $95 \%$ probability, for accessions with low (a), intermediate (b) and high (c), mean grades of bacterial wilt symptoms.

coefficient of the accessions BAF $122(0.06)$, BAF $23(0.06)$ and BAF 108 (0.07).

Xan 159 is an important source of genes for common bean breeding programs, since it is also resistant to common bacterial blight caused by Xanthomonas campestris pv. phaseoli, demonstrated in two QTL regions that determine this resistance (Jung et al. 1997). It can be used as allelle donor in crosses to develop cultivars with acceptable resistance levels to two bacterial diseases of common bean. But although 159 Xan is a great source of tolerance to bacterial wilt and common bacterial blight, the grain quality is exotic and of marginal economic importance in Brazil. Certainly more breeding work is required until this tolerance source becomes useful, especially in view of the quantitative genetic control of the disease.
The tolerance of accessions is related to the presence of resistance mechanisms such as tylosis formation and the presence of fibrils around the bacterial cells that prevent cell growth and movement through xylem vessels. The characteristic symptoms of bacterial wilt are therefore not observed (Souza et al. 2006, Souza and Maringoni 2008). In contrast, no resistance mechanisms occur in susceptible accessions, allowing the bacterial cells to proliferate, increasing the disease symptoms.

The cultivars IAC Carioca Aruã, IAC Carioca Pyatã and IAC Cariocato Tybatã showed tolerance to bacterial wilt with mild disease symptoms (Table 1). The cultivars IAC Carioca Aruã, IAC Carioca Pyatã and also IAC Carioca Akytã, according to Maringoni (2002), are the only registered cultivars with bacterial-wilt resistance, while the 
others are extremely susceptible to the disease. In studies developed by Souza et al. (2006), IAC Carioca Tybatã was considered resistant since no disease-symptoms were observed. However, in this study disease symptoms were observed on the cultivars, which were therefore considered tolerant rather than resistant, as mentioned in other studies. Studies evaluating the genetic resistance to bacterial wilt in some common bean genotypes by different authors show different reactions of a same genotype. The reasons are variations in experimental conditions and different bacterial isolates (Souza et al. 2006).

The fact that most common bean varieties recommended today in Brazil are susceptible represents a serious threat of the crop, because this disease could become problematic for susceptible cultivars under field conditions favoring the occurrence of epidemics (Maringoni 2002). On the other hand, the existence of some tolerant genotypes is important, so there are cultivars available for regions with $100 \%$ disease incidence.

The identification of genes that confer resistance or tolerance to bacterial wilt is the first step towards success in a breeding program. Thereafter, research should target specific issues such as knowledge of the phenotype of the host reaction, the number of genes involved in each reaction, interactions with the environment, the genetic mechanisms involved as well as the identification of molecular markers for marker-assisted selection. This technique is extremely valuable in breeding programs, since the genes available can be used to obtain a consistent protection against the pathogen (Rava et al. 2004, Almeida et al. 2007).

In conclusion, the accession BAF 122 (Xan 159) is tolerant to isolate Cff 2634 of Curtobacterium flaccumfaciens pv. flaccumfaciens, and is indicated for breeding programs targeting resistant genotypes.

\section{ACKNOWLEDGEMENTS}

The authors thank the Fundação de Apoio à Pesquisa Científica e Tecnológica do Estado de Santa Catarina FAPESC and Conselho Nacional de Desenvolvimento Científico e Tecnológico (CNPq) for financial support, and are indebted to Professor Antonio Carlos Maringoni of the Universidade Estadual Paulista Julio de Mesquita Filho (UNESP) for providing the isolate and to the researcher Sérgio Augusto Carbonell of the Instituto Agronômico de Campinas (IAC) for providing basic seeds.

\section{Fontes de resistência à Curtobacterium flaccumfaciens pv. flaccumfaciens em acessos de feijão}

RESUMO - O objetivo deste trabalho foi identificar genótipos de feijão resistentes à murcha de curtobacterium, para que possam ser utilizados como fontes de resistência em programas de melhoramento, para o desenvolvimento de cultivares resistentes. Foram avaliados 67 acessos, cinco cultivares e uma testemunha, as quais foram inoculadas artificialmente, utilizando o isolado de Curtobacterium flaccumfaciens $p v$. flaccumfaciens Cff 2634. Os resultados comprovam a existência de alelos que conferem tolerância à murcha de curtobacterium nas cultivares IAC Carioca Aruã, IAC Carioca Pyatã e IAC Carioca Tyabatã. Entre os acessos foi possível identificar o BAF 122 (Xan 159) como tolerante à doença, pois apresentou as menores médias para os sintomas, sendo indicado para uso em programas de melhoramento para o desenvolvimento de cultivares resistentes.

Palavras-chave: Phaseolus vulgaris L.; murcha de curtobacterium; Banco Ativo de Germoplasma.

\section{REFERENCES}

Almeida AB, Chaves MS, Brammer SP and Baggio MI (2007) Identificação de fontes de resistência à ferrugem da folha do trigo em acessos de Aegilops tauschii. Fitopatologia Brasileira 32: 349-352.
Coyne DP, Schuster ML and Young JO (1965) A genetic study of bacterial wilt (Corynebacterium flaccumfaciens var. aurantiacum) tolerance in Phaseolus vulgaris crosses and the development of tolerance to two bacterial diseases in beans. Journal of the American Society for Horticultural Science 87: 279-85. 
G Valentini et al.

Herbes DH, Theodoro GF, Maringoni AC, Dal Piva CA and Abreu L (2008) Detecção de Curtobacterium flaccumfaciens pv. flaccumfaciens em sementes de feijoeiro produzidas em Santa Catarina. Tropical Plant Pathology 33: 53-156.

Jung G, Skroch PW, Coyne DP, Nienhuis J, Arnaud-Santana E, Ariyarathen HM, Kaeppler SM and Bassett MJ (1997) Molecular-marker-based genetic analysis of tepary bean-derived common bacterial blight resistance in different development stages of common bean. Journal of the American Society for Horticultural Science 122: 329-337.

Krause W, Rodrigues R, Gonçalves LSA, Bezerra Neto FV and Leal NR (2009) Genetic divergence in snap bean based on agronomic traits and resistance to bacterial wilt. Crop Breeding and Applied Biotechnology 9: 246-252.

Littell RC, Milliken GA, Stroup WW, Wolfinger RD and Schabenberger O (2006) SAS for mixed models. SAS, Cary, 814 p.

Maringoni AC (2002) Comportamento de cultivares de feijoeiro comum à murcha-de-curtobacterium. Fitopatologia Brasileira 27: 157-162.

Maringoni AC and Rosa EF (1997) Ocorrência de Curtobacterium flaccumfaciens $p v$. flaccumfaciens em feijoeiro no Estado de São Paulo. Summa Phytopathologica 23: 160-162.

Maringoni AC and Camara RC (2006) Curtobacterium flaccumfaciens pv. flaccumfaciens detection in bean seeds using a semi-selective culture medium. Brazilian Journal of Microbiology 37: 451-455.

Mutlu N, Miklas P, Reiser J and Coyne D (2005) Backcross breeding for improved resistance to common bacterial blight in pinto bean (Phaseolus vulgaris L.). Plant Breeding 124: 282-287.

Rava CA, Costa JGC, Fonseca JR and Salgado AL (2004) New sources of resistance to bacterial wilt identified in dry bean germplasm collection. Crop Breeding and Applied Biotechnology 4: 111-114.
Romero RS (2005) Bactérias fitopatogênicas. Editora UFV, Viçosa, 417p.

Souza VL, Maringoni AC, Sérgio AMC and Ito MF (2006) Resistência genética em genótipos de feijoeiro a Curtobacterium flaccumfaciens pv. flaccumfaciens. Summa Phytopathologica 32: $339-344$

Souza VL and Maringoni AC (2008) Análise ultraestrutural da interação de Curtobacterium flaccumfaciens pv. flaccumfaciens em genótipos de feijoeiro. Summa Phytopathologica 34: 318-320.

Theodoro GF, Herbes DH and Maringoni AC (2007) Fontes de resistência à murcha de curtobacterium em cultivares locais de feijoeiro, coletadas em Santa Catarina. Ciência e Agrotecnologia 31: 333-339.

Theodoro GF and Maringoni AC (2006) Murcha-de-curtobacterium do feijoeiro no Estado de Santa Catarina e reação de genótipos a Curtobacterium flaccumfaciens pv. flaccumfaciens. Summa Phytopathologica 32: 34-41.

Theodoro GF, Maringoni AC and Hemp S (2004) Distribuição de Curtobacterium flaccumfaciens pv. flaccumfaciens em lavouras de feijoeiro comum no estado de Santa Catarina. Fitopatologia Brasileira 29: 39 .

Uesugi CH, Freitas MA and Menezes JR (2003) Ocorrência de Curtobacterium flaccumfaciens pv. flaccumfaciens em feijoeiro, em Goiás e no Distrito Federal. Fitopatologia Brasileira 28: 324. 